\author{
Research article \\ urn:lsid:zoobank.org:pub:02A1C7B1-CE07-4BB8-BC6C-3B596598A8C3
}

\title{
Two new species of cheilostomate Bryozoa from Iberian waters
}

\author{
Oscar REVERTER-GIL ${ }^{\circledR 1, *} \&$ Javier SOUTO ${ }^{\circledR} 2$ \\ ${ }^{1}$ Museo de Historia Natural da Universidade de Santiago de Compostela, Parque Vista Alegre s/n, \\ 15705 Santiago de Compostela, Spain. \\ ${ }^{2}$ Institut für Paläontologie, Fakultät für Geowissenschaften, Geographie und Astronomie, Geozentrum, \\ Universität Wien, Althanstrasse 14, 1090 Wien, Austria. \\ *Corresponding author: oscar.reverter@usc.es \\ ${ }^{2}$ Email: javier.souto-derungs@univie.ac.at \\ ${ }^{1}$ urn:1sid:zoobank.org:author:001DFC48-0F01-43AF-90EC-452BE6954DDF \\ ${ }^{2}$ urn:Isid:zoobank.org:author:E14FC8A9-40B5-4BF6-8551-3F2A1D991463
}

\begin{abstract}
Two new species of cheilostomate bryozoans are described from material preserved in museums: Cradoscrupocellaria severoi sp. nov., from Iberian Mediterranean waters, and Setosella margaritae sp. nov., from shallow waters along the Atlantic coast of Europe. Moreover, the Mediterranean species Setosella cyclopensis Rosso, Di Martino \& Gerovasileiou, 2020 is reported in Iberian waters for the first time.
\end{abstract}

Keywords. Cradoscrupocellaria, Setosella, Setosella cyclopensis, Spain, Europe.

Reverter-Gil O. \& Souto J. 2021. Two new species of cheilostomate Bryozoa from Iberian waters. European Journal of Taxonomy 760: 16-31. https://doi.org/10.5852/ejt.2021.760.1437

\section{Introduction}

Although no complete catalogue is currently available, we consider that the bryozoological fauna of the Iberian Peninsula is one of the best known in European waters, with approximately 540 recent species cited in this region (about 420 along the Atlantic coast and about 340 along the Mediterranean coast; own unpublished compilation). Nonetheless, our overall knowledge remains fragmentary and undoubtedly includes many taxonomic errors, which are gradually being corrected in various studies. The greater ease of access to original reference material and, above all, the use of the electron microscope enable better characterization of species, and makes possible to detect misidentifications and misinterpretations of the species concept as well. Revision of material stored in collections has thus become an essential part of the work of taxonomists, either to redescribe known species or to describe new ones.

The genus Cradoscrupocellaria Vieira, Spencer Jones \& Winston, 2013 was recently described after a major revision of species originally ascribed to the genus Scrupocellaria s. lat. Cradoscrupocellaria reptans (Linnaeus, 1758) was redescribed by Vieira \& Spencer Jones (2012). On the other hand, Rosso et al. (2020) also very recently redescribed the genus Setosella Hincks, 1877, and Souto et al. (2016) redescribed its type species, $S$. vulnerata (Busk, 1860). These taxonomic revisions made it necessary 
to study and correct previous records in order to update the identification of certain specimens. Based on the revision of material preserved in museums, we present here two new species of cheilostomate Bryozoa belonging to the genera Cradoscrupocellaria and Setosella. We also report the Mediterranean species Setosella cyclopensis Rosso, Di Martino \& Gerovasileiou, 2020 in Iberian waters for the first time. This extends our knowledge of the bryozoan fauna in Iberian waters and in Europe as a whole.

\section{Material and methods}

\section{Institutional abbreviations}

Samples deposited in the collections of the following museums have been revised:

$$
\begin{aligned}
& \text { MHNUSC }=\text { Museo de Historia Natural da Universidade de Santiago de Compostela } \\
& \text { MNCN }=\text { Museo Nacional de Ciencias Naturales, Madrid } \\
& \text { MNHN }=\text { Muséum national d'histoire naturelle, Paris } \\
& \text { NHMUK }=\text { Natural History Museum, London }
\end{aligned}
$$

The samples were examined with stereomicroscopes and uncoated, clean specimens were selected to photograph with scanning electron microscopes: a Zeiss EVO LS15 (Santiago de Compostela, Spain) and an Inspect S50 (Vienna, Austria and Madrid, Spain), always with a back-scattered electron detector in low variable vacuum mode. Measurements were taken with the software Image J® on SEM photographs.

\section{Results}

Order Cheilostomatida Busk, 1852

Suborder Flustrina Smitt, 1868

Superfamily Buguloidea Gray, 1848

Family Candidae d'Orbigny, 1851

Genus Cradoscrupocellaria Vieira, Spencer Jones \& Winston, 2013

Cradoscrupocellaria severoi $\mathrm{sp}$. nov.

urn:lsid:zoobank.org:act:AF6D2F75-42FE-4AD5-A1A2-A8D587ECA7F7

Figs 1-2; Table 1

Scrupocellaria reptans - Templado et al. 2002: 203.

? Scrupocellaria macrorhyncha - Zabala 1986: 318, fig. 88, pl. 3 figs a-d.

? Scrupocellaria reptans - Zabala \& Maluquer 1988: 97, figs 159-160, pl. 5 figs a-b.

\section{Differential diagnosis}

Cradoscrupocellaria with erect, branched colonies, with internodes comprising 5-10 alternating autozooids. Chitinous joints passing across proximal gymnocyst of outer and inner zooids. Large scutum, stout and flat, highly branched, completely covering the opesia. Two inner spines and 3 outer spines. Small distolateral avicularium frequent. Large monomorphic frontal avicularium in outer zooids oriented upwards on the branch. Ovicells globular, wider than long, perforated by 10-18 rounded pores; ovicelled zooids with 2 inner and 2 outer spines.

\section{Etymology}

This species is dedicated to Severo Ochoa de Albornoz (1905-1993), Spanish physician and biochemist, winner of the 1959 Nobel Prize in Physiology or Medicine for the discovery of the mechanisms in the biological synthesis of nucleic acids. 


\section{Material examined}

Holotype

MEDITERRANEAN SPAIN • colony; Columbretes Islands; 39 $87.967^{\prime} \mathrm{N}, 0^{\circ} 66.817^{\prime}$ E; stn 277B15; depth 3-40 m; 1996; Fauna Ibérica IV exped.; MNCN 25.03/3059 (Figs 1A, D, 2A, D).

\section{Paratypes}

MEDITERRANEAN SPAIN • 1 colony; Columbretes Islands; $39^{\circ} 85.450^{\prime} \mathrm{N}, 0^{\circ} 67.617^{\prime} \mathrm{E}$; stn 285B1; depth 42 m; 1996; Fauna Ibérica IV exped.; MNCN 25.03/2999 • several fragments; Columbretes Islands; $39^{\circ} 87967^{\prime} \mathrm{N}, 0^{\circ} 66817^{\prime} \mathrm{E}$; stn 277B14; depth $7.5 \mathrm{~m}$; 1996; Fauna Ibérica IV exped.;
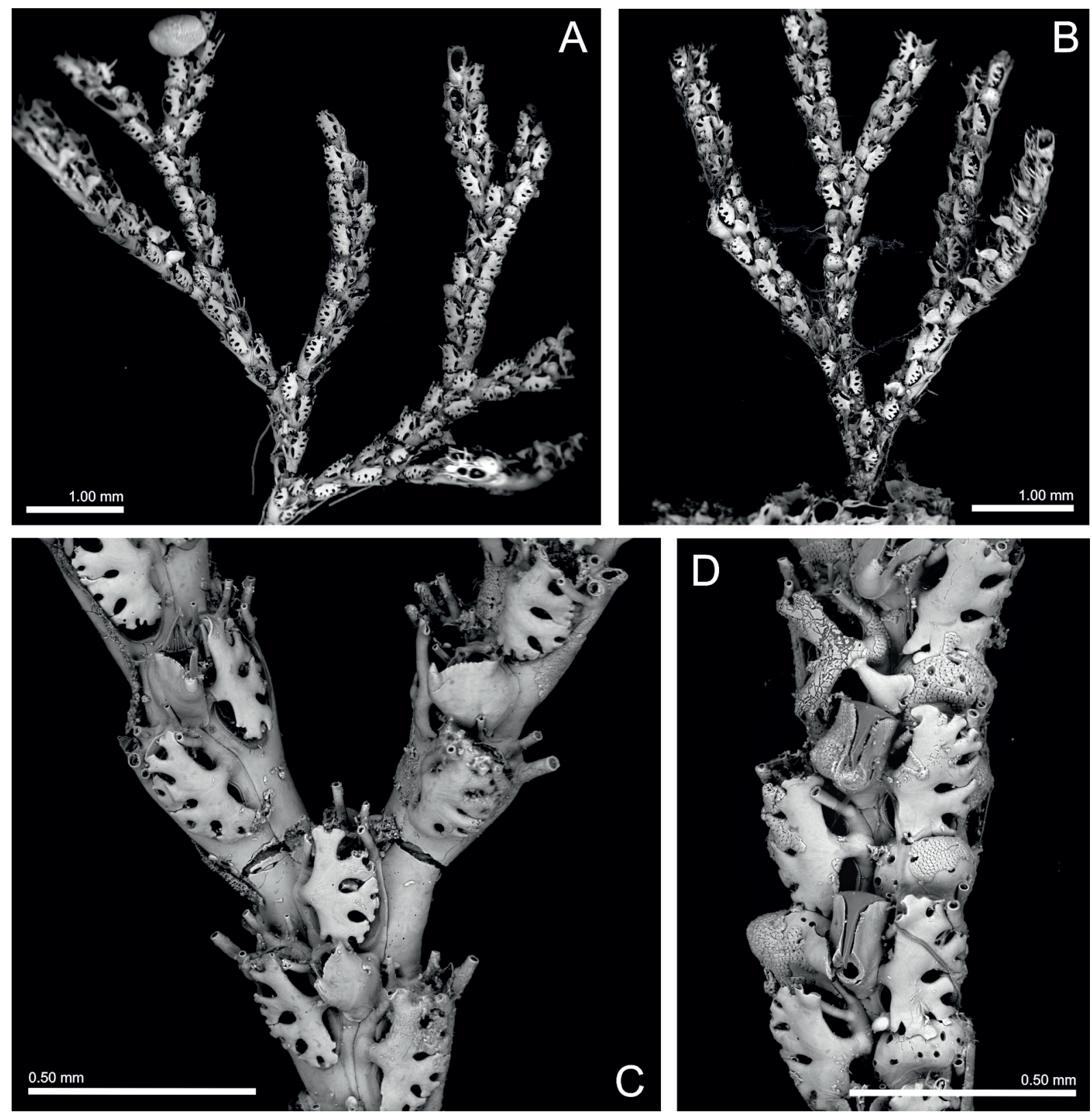

Fig. 1. Cradoscrupocellaria severoi sp. nov. A. View of the colony (MNCN 25.03/3059: holotype). B. View of the colony (MNCN 25.03/3200: paratype). C. Branching pattern (MNCN 25.03/4234: paratype). D. Detail of a branch with large frontal avicularia, ovicells and scuta (MNCN 25.03/3059: holotype). 
MNCN 25.03/3057, 25.03/4234 (Figs 1C, 2C) • several fragments; Columbretes Islands; 3989.800' N, $0^{\circ} 68.883^{\prime}$ E; stn 275B5; depth 35 m; 1996; Fauna Ibérica IV exped.; MNCN 25.03/3200 (Figs 1B, 2B).

\section{Other material}

Paralectotypes of Scrupocellaria macrorhyncha Gautier, 1962 (here designated, see explanation below):

MEDITERRANEAN FRANCE • several fragments; Marseille, SW Cap Caveaux; stn 258; 1 Dec. 1952; Gautier leg.; MNHN-IB-2008-11319 • several fragments; same collection data as for preceding; MNHNIB-2008-11321 (Fig. 3).

\section{Description}

Colony erect, up to $1 \mathrm{~cm}$ in height, branched, with internodes comprising 5-10 alternating autozooids. Internodes slender, almost straight, angled at axis, with acute bifurcating pattern; chitinous joints
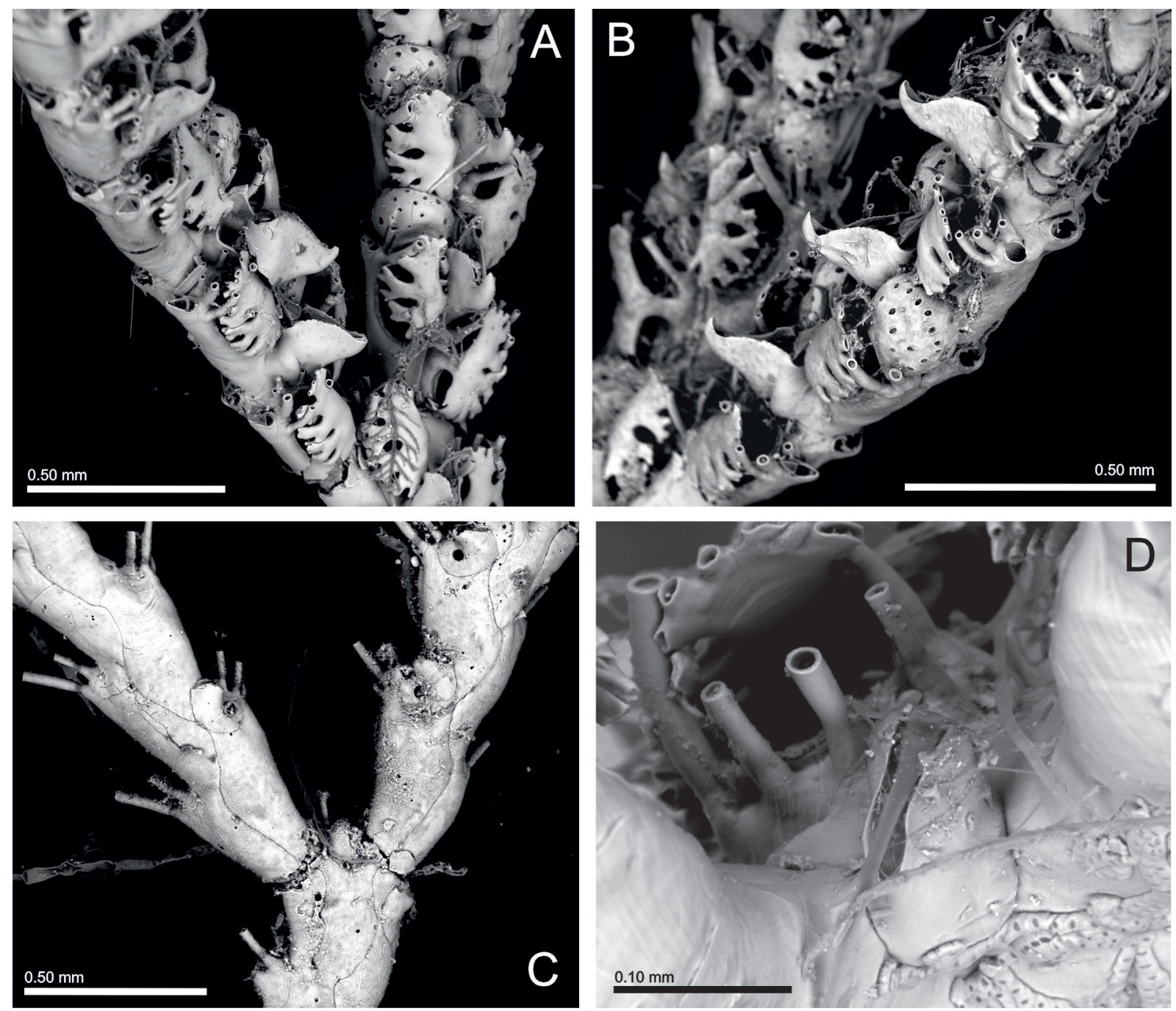

Fig. 2. Cradoscrupocellaria severoi sp. nov. A. Detail of branches with large frontal avicularia, ovicells, scuta and a lateral avicularium (centre left) (MNCN 25.03/3059: holotype). B. Detail of a branch with large frontal avicularia, ovicells and a lateral avicularium (bottom left) (MNCN 25.03/3200: paratype). C. Basal view of the branching pattern (MNCN 25.03/4234: paratype). D. Single axial vibraculum (MNCN 25.03/3059: holotype). 
passing across proximal gymnocyst of outer ( $\mathrm{C}$ and $\mathrm{D}$ ) and inner zooids ( $\mathrm{F}$ and $\mathrm{G}$ ) at bifurcation. Autozooids cylindrical with straight sides. Oval opesia occupying two thirds of zooidal length; cryptocyst reduced to narrow rim around opesia. Large scutum inserted at midline of the inner edge of opesia, stout but relatively flat, its tips highly branched, fully developed and completely covering entire opesia. Distal spines short, unbranched; 2 inner and 3 outer spines, with outer distal spines closer to scutum; axial zooid with 5 spines. Small distolateral avicularium frequent and easily visible in frontal view. Monomorphic frontal avicularium often present in outer zooids of each internode; large but variable in size, with elongate rostrum $0.22-0.28 \mathrm{~mm}$ long, with fringed edges, proximally upright, with strongly hooked tip; mandible long, hooked distally. Vibracular chamber laterally placed on the basal surface of each zooid, visible in frontal view; chamber of vibraculum almost trapezoidal, with a proximal rhizoidal foramen; setal groove transverse to internode axis, straight, with smooth seta longer than one autozooid. Single axial vibraculum without rhizoidal foramen. Rhizoids tubular and smooth. Ovicells globular, wider than long, with an even, almost straight proximal rim; ectooecium perforated by $10-18$ rounded pores; ovicelled zooids with 2 inner and 2 outer spines. Ancestrula unknown.

\section{Remarks}

The genus Cradoscrupocellaria has been recently described by Vieira et al. (2013). Nine already existing species were transferred to this genus, and the same authors described 18 new species. Among all these species, only C. gautieri Vieira, Spencer Jones \& Winston, 2013 and C. macrorhyncha (Gautier, 1962) show similarities with $C$. severoi sp. nov., mainly regarding the very stout scutum with truncate tips and the large frontal avicularia. The description of $C$. gautieri is based on a single sample collected by Gautier (1962) in Algeria. Cradoscrupocellaria macrorhyncha was redescribed by Vieira et al. (2013) based on the only original sample of Gautier deposited at NHMUK, designated as lectotype, and other Mediterranean samples by other authors. However, the MNHN collection includes two other original samples of Gautier from the same station as the lectotype that seem to have been overlooked in the redescription of the species, perhaps because in the museum's catalogue and in the external labels of the samples both are simply marked as "Scrupocellaria reptans": sample MNHN-IB-2008-11319 contains a handwritten label by Gautier stating "Scrupocellaria reptans group? Dry specimen"; being written in English, it is highly probable that this sample together with the lectotype were sent by Gautier to A. Hastings at the NHMUK, and later returned. Sample MNHN-IB-2008-11321 (Fig. 3) includes a label handwritten by Gautier indicating "Scrupocellaria reptans? grand avic.". Since both samples actually correspond to C. macrorhyncha and were collected by Gautier at the type locality of the species and studied by him, they should be considered as part of the type series and consequently considered as paralectotypes of the species according to Arts 73.2.2 and 74.1.3 of the ICZN Code (ICZN 1999).

Cradoscrupocellaria severoi sp. nov. differs from C. macrorhyncha and C. gautieri by several characters: the frontal avicularium is monomorphic in $C$. severoi sp. nov. because the small columnar avicularium present in the other species is absent; this frontal avicularium is oriented upwards on the branch, not proximally (Figs 2A-B, 3C). The lateral avicularium is more frequent and more visible (Fig. 2A-B). In the bifurcations of $C$. severoi sp. nov., the chitinous joints pass through the gymnocyst of the external zooids (C and D) instead of through their opesiae (Figs 1C, 3A). The ovicell is wider than long in C. severoi sp. nov., usually uniformly perforated by small pseudopores (Figs 1D, 2A-B), whilst in C. macrorhyncha the ovicell is more spherical and usually exhibits an imperforate flat frontal area (Fig. 3B) (in C. gautieri the ovicell is unknown). The autozooids of $C$. severoi sp. nov. are clearly smaller than those of C. macrorhyncha, but similar in size to those of C. gautieri. Finally, the internodes are short in C. severoi sp. nov., formed by 5-10 autozooids (Fig. 1A-B), as in C. gautieri, but the scutum is flatter and not swollen as in that latter species. 
Table 1. Measurements (in mm) of Cradoscrupocellaria severoi sp. nov. (holotype + paratypes). Abbreviations: $\mathrm{SD}=$ standard deviation, $\mathrm{N}=$ number of measurements.

\begin{tabular}{lccccc}
\hline & Mean & SD & Minimum & Maximum & N \\
\hline Autozooid length & 0.454 & 0.0480 & 0.370 & 0.565 & 29 \\
Autozooid width & 0.191 & 0.0154 & 0.161 & 0.232 & 29 \\
Sutum length & 0.289 & 0.0176 & 0.258 & 0.324 & 29 \\
Scutum width & 0.164 & 0.0206 & 0.121 & 0.207 & 29 \\
Frontal avic. length & 0.259 & 0.0283 & 0.218 & 0.281 & 4 \\
Frontal avic. width & 0.087 & 0.0037 & 0.082 & 0.093 & 6 \\
Lateral avic. length & 0.065 & 0.0080 & 0.055 & 0.073 & 6 \\
Ovicell length & 0.163 & 0.0160 & 0.134 & 0.186 & 18 \\
Ovicell width & 0.213 & 0.0187 & 0.170 & 0.245 & 18 \\
\hline
\end{tabular}
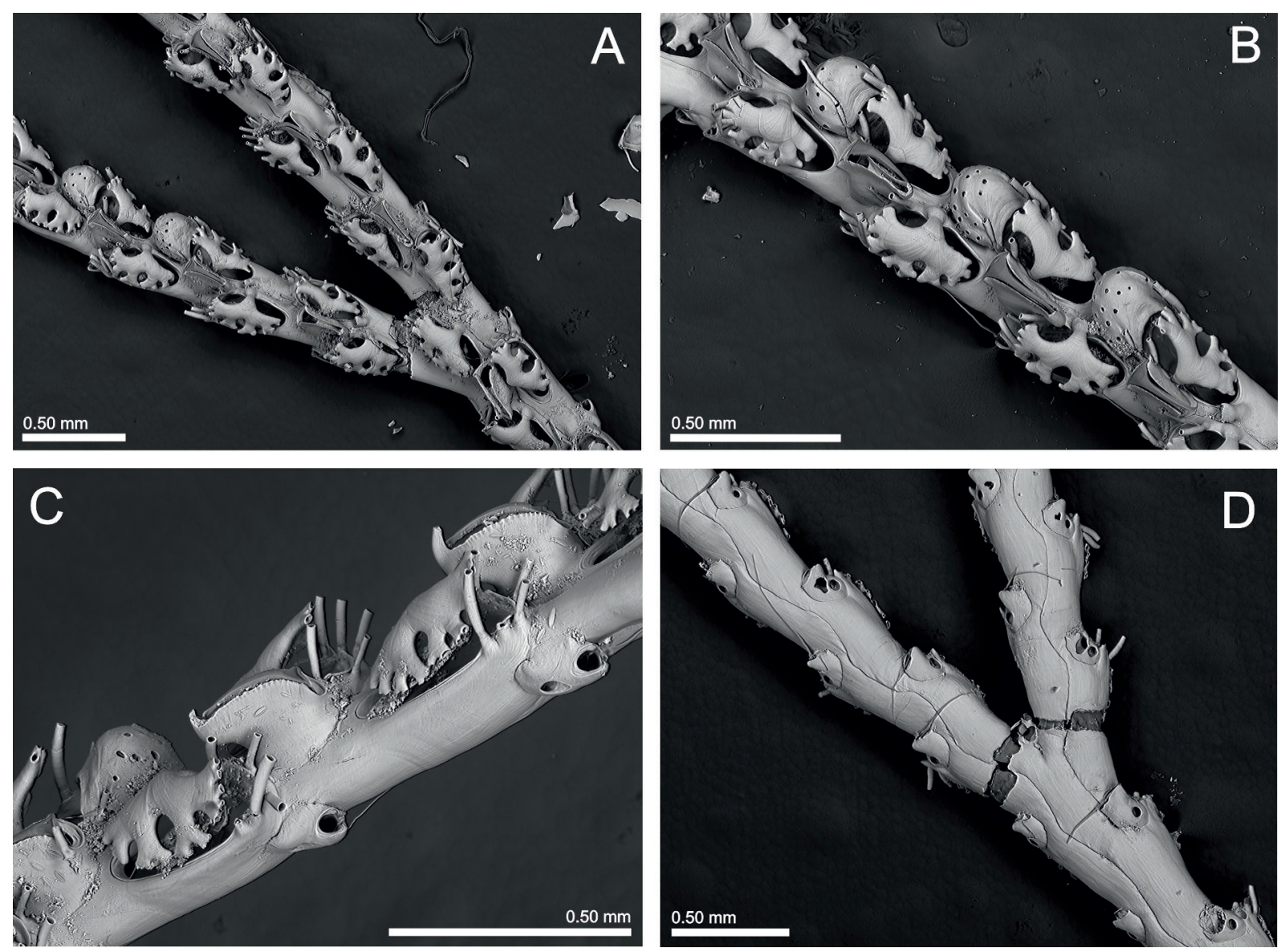

Fig. 3. Cradoscrupocellaria macrorhyncha (Gautier, 1962) (MNHN-IB-2008-11321: paralectotype), SW Cap Caveaux (Marseille, France), Gautier Coll. A. Frontal view of the branching pattern. B. Detail showing the scuta, ovicells, large frontal avicularia and a small frontal avicularium (bottom right). C. Lateral view showing the large frontal avicularia and basal vibracula. D. Basal view of the branching pattern. 
Cradoscrupocellaria severoi sp. nov. is known with certainty only from its type localities at the Columbretes Islands (Mediterranean Spain) between 3 and $42 \mathrm{~m}$ depth. Zabala (1986) reported Scrupocellaria macrorhyncha Gautier, 1962 from several Catalonian localities, but these records were later reassigned to S. reptans (Linnaeus, 1758) by Zabala \& Maluquer (1988). Vieira et al. (2013), however, stated that these specimens are distinct from C. macrorhyncha and C. reptans, as well as from C. ellisi (Vieira \& Spencer Jones, 2012), and that they may belong to a new undescribed species. Figures by Zabala (1986) and Zabala \& Maluquer (1988) are quite similar to C. severoi sp. nov., but the description given (actually an almost literal translation of the original description of $S$. macrorhyncha by Gautier) show several differences from the present description of the new species. A revision of the original material and collection of new material will be necessary to clarify which species was reported from Catalonia, as well as to determine the possible presence of $C$. severoi sp. nov. at other Iberian localities.

\author{
Superfamily Microporoidea Gray, 1848 \\ Family Setosellidae Levinsen, 1909 \\ Genus Setosella Hincks, 1877 \\ Setosella margaritae sp. nov. \\ urn:1sid:zoobank.org:act:E9976DD1-53EC-4547-A766-37B1DEE466DF
}

Figs $4-5$, Table 2

Setosella vulnerata - Reverter-Gil et al. 1992: 102, fig. 2; 2016: 28, fig. 4d. — Barcia Leal et al. 1993: 251. - Reverter-Gil 1995: 115, fig. 7. — Hayward \& Ryland 1998: 298, fig. 103. — Reverter-Gil \& Fernández-Pulpeiro 2001: 78 (shallow waters only). — De Blauwe 2006: 130, fig. 9; 2009: 252, figs 257-258.

Non Setosella vulnerata - Jullien 1882: 28, pl. 17 fig. 66. — Calvet 1907: 394. — d'Hondt 1973: 367; 1974: 38. - Hayward 1979: 60. — Reverter-Gil \& Fernández-Pulpeiro 2001: 78 (deep waters only). - Templado et al. 2006: 208. - Reverter-Gil et al. 2014: 16. — Souto et al. 2016: 416, figs 33, 38. - Rosso et al. 2020: 403, figs 1-2 [= Setosella vulnerata (Busk, 1860)].

Non Setosella vulnerata - Templado et al. 2002: 203. (= Setosella cyclopensis Rosso, Di Martino \& Gerovasileiou, 2020).

\title{
Differential diagnosis
}

Setosella with small, encrusting colonies. Autozooids small, oval, with opesia D-shaped or irregularly rounded, and two oval to tear-shaped opesiules, positioned close to opesia and directly beside lateral walls of zooid. Small interzooidal vibracula oval, positioned distolateral to each autozooid, always on the right side and often without exceeding distal edge of autozooid, especially in ovicelled ones. Ectooecium with transversely oval membranous window and granular endooecial surface underneath, with a small, central pore. Ancestrula oval, with cryptocyst occupying slightly less than half of the frontal area; opesia semielliptical, with straight or slightly concave proximal border.

\section{Etymology}

This species is dedicated to Margarita Salas Falgueras (1938-2019), Spanish scientist, medical researcher, and author in the fields of biochemistry and molecular genetics. She was a disciple of S. Ochoa (see above). 


\section{Material examined}

\section{Holotype}

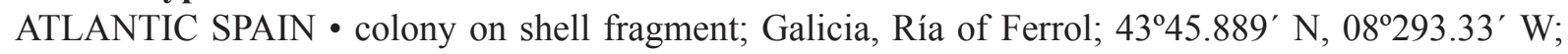
depth 20 m; 13 Sep. 1989; Reverter-Gil leg.; MHNUSC 10120; (Fig. 4A-B).

\section{Paratypes}

ATLANTIC SPAIN - several small juvenile colonies on shell fragment; same collection data as for holotype; MHNUSC 10121 (Fig. 4C) • colony on shell fragment; same collection data as for holotype; MHNUSC 10122 (Fig. 5C-D) • small eroded colony on shell fragment; Galicia, Ría of Ferrol; $43^{\circ} 45.500^{\prime} \mathrm{N}, 08^{\circ} 30.889^{\prime}$ W; depth 12 m; 13 Sep. 1989; Reverter-Gil leg.; MHNUSC 10123 (Figs 4D, $5 \mathrm{~B})$.
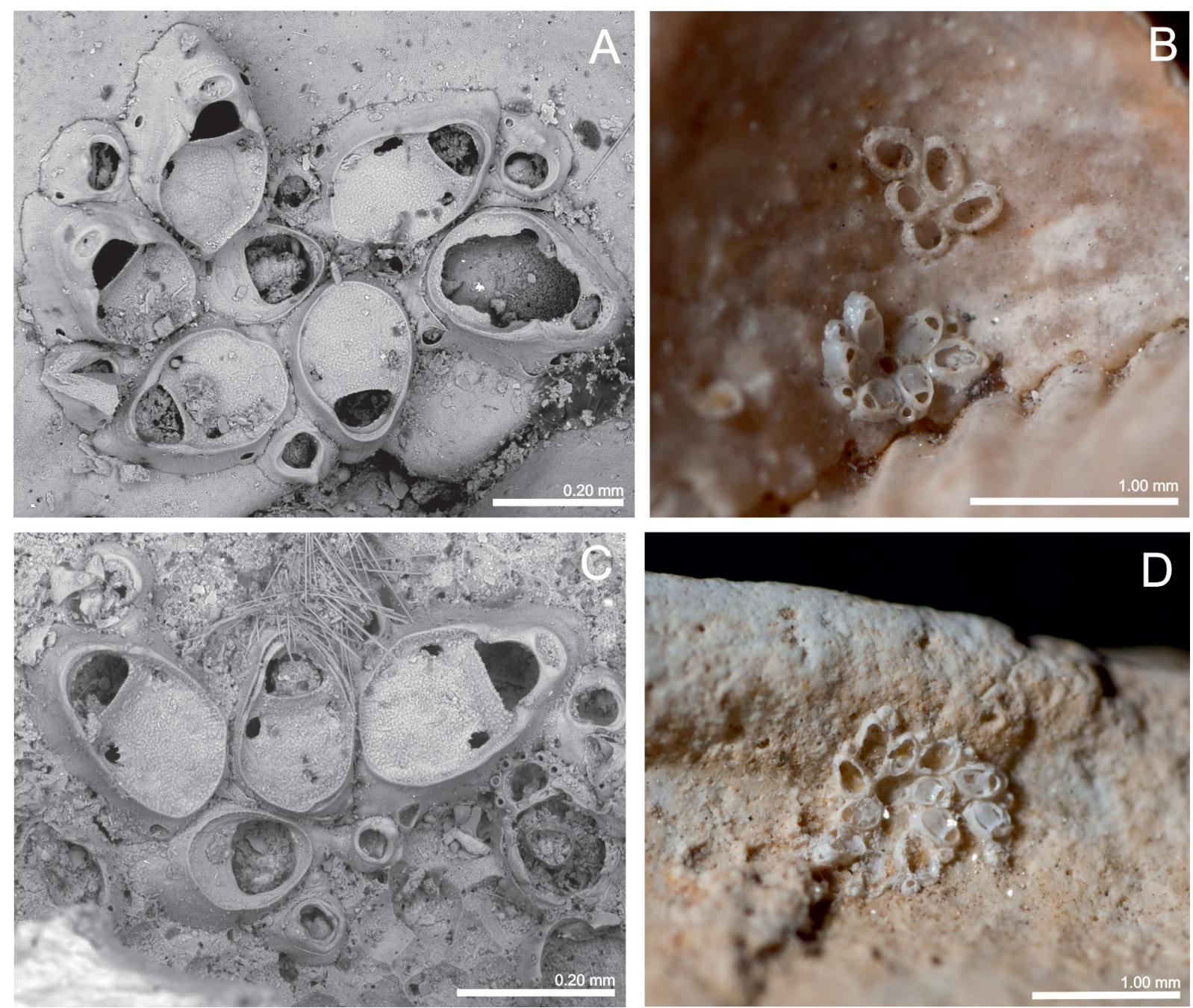

Fig. 4. Setosella margaritae sp. nov. A. Holotype (MHNUSC 10120). B. Same, optical photograph, together with a small, dead colony of Callopora discreta (Hincks, 1862) encrusting the inner part of a barnacle plate. C. Ancestrula with reversed astogenetic pattern (note the short vibraculum positioned on the right side) (MHNUSC 10121: paratype). D. Optical photograph of a damaged colony on a shell fragment (MHNUSC 10123: paratype). 
Table 2. Measurements (in $\mathrm{mm}$ ) of Setosella margaritae sp. nov. (holotype + paratypes). $\mathrm{SD}=$ standard deviation, $\mathrm{N}=$ number of measurements.

\begin{tabular}{lccccc}
\hline & Mean & SD & Minimum & Maximum & N \\
\hline Autozooid length & 0.250 & 0.0604 & 0.174 & 0.350 & 9 \\
Autozooid width & 0.170 & 0.0436 & 0.120 & 0.227 & 9 \\
Opesia length & 0.055 & 0.0137 & 0.038 & 0.070 & 9 \\
Opesia width & 0.075 & 0.0213 & 0.050 & 0.096 & 9 \\
Vibraculum length & 0.091 & 0.0245 & 0.059 & 0.135 & 13 \\
Vibraculum width & 0.087 & 0.0231 & 0.055 & 0.131 & 13 \\
Ooecium length & 0.049 & 0.0164 & 0.038 & 0.073 & 4 \\
Ooecium width & 0.077 & 0.0200 & 0.062 & 0.105 & 4 \\
Ancestrula length & 0.239 & 0.0295 & 0.220 & 0.273 & 3 \\
Ancestrula width & 0.159 & 0.0366 & 0.124 & 0.197 & 3 \\
Ancestr. opesia length & 0.106 & 0.0061 & 0.099 & 0.110 & 3 \\
Ancestr. opesia width & 0.099 & 0.0068 & 0.091 & 0.104 & 3 \\
\hline
\end{tabular}

\section{Other material}

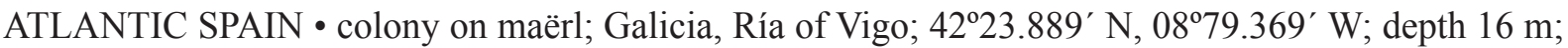
16 Sep. 1986; Fernández-Pulpeiro leg.; MHNUSC-Bry 93a (together with Setosella sp.) (Fig. 5A) - colony on shell fragment; Galicia, Ría of Vigo; $42^{\circ} 23.139^{\prime}$ N, $08^{\circ} 76.389^{\prime}$ W; depth 9 m; 16 Sep. 1986; Fernández-Pulpeiro leg.; MHNUSC-Bry 93b - colony on shell fragment; Galicia, Ría of Vigo; $42^{\circ} 22.944^{\prime} \mathrm{N}, 08^{\circ} 88.056^{\prime} \mathrm{W}$; depth 23 m; 2 Aug. 1985; Fernández-Pulpeiro leg.; MHNUSC-Bry 93c (together with Trypostega venusta (Norman, 1864) and Microporella ciliata (Pallas, 1766)) - colony

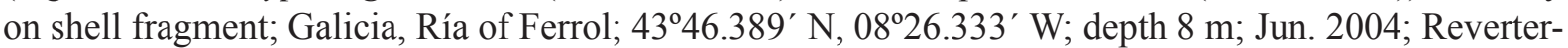
Gil leg.; MHNUSC-Bry 656 (together with 12 spp. more).

\section{Lectotype of Setosella vulnerata}

NORTH SEA•UK, Shetland; Busk leg.; NHMUK 1899.7.1.1487 (see also Souto et al. 2016).

\section{Paralectotypes of Setosella vulnerata}

NORTH SEA • several colonies; UK, Shetland; Busk leg.; NHMUK 1911.10.1.760 (see also Souto et al. 2016).

\section{Other material of Setosella vulnerata}

MEDITERRANEAN SPAIN • Alboran Island; 35 $83.550^{\prime} \mathrm{N}, 03^{\circ} 23.667^{\prime} \mathrm{W}$; stn 313A; depth $118 \mathrm{~m}$; 1996; Fauna Ibérica IV exped.; MNCN 25.03/3169 (Fig. 6).

\section{Material of Setosella cyclopensis}

MEDITERRANEAN SPAIN • Columbretes Islands; 39 87.217' N, $0^{\circ} 63.400^{\prime}$ E; stn 283A; depth 80 85 m; 1996; Fauna Ibérica IV exped.; MNCN 25.03/3149.

\section{Description}

Colony encrusting, unilaminar, forming small discoidal patches of alternating autozooids and vibracula. Autozooids irregularly oval, with well-developed smooth gymnocyst proximally that narrows and steepens distally, lateral walls slightly raised, framing an evenly granular cryptocyst that is flat and depressed proximally, gently rising distally to the opesiules to form the proximal border of the opesia. 
Opesia D-shaped or irregularly rounded, wider than long, distal margin with some blunt, irregularly spaced denticles. Two oval to tear-shaped opesiules (ca $20 \mu \mathrm{m}$ long by $10 \mu \mathrm{m}$-wide), located in distal depressed area of the cryptocyst, positioned close to the opesia (mean $36 \mu \mathrm{m}$ ) and directly beside the lateral walls of zooid, their inner edges sometimes with several sharp denticles; the size of both opesiules unequal, the left one slightly larger. Small interzooidal vibracula oval, positioned distolateral to each autozooid, always on the right side and often without exceeding the distal edge of the autozooid, especially in ovicelled ones. Wide oval opesia, sometimes slightly narrower in the middle; seta long and slender, curved, up to twice length of the autozooid. Communication of zooids via small uniporous septula. Some autozooids and vibracula show evidence of breakage and regeneration associated with the intramural budding (Fig. 5C-D). Ovicells terminal, with a brood cavity immersed within the distal part of the maternal zooid. Kenozooidal ooecium roughly level with the colony surface, forming shallow hood covering distal end of the maternal zooid from which it is budded. Proximal ooecial margin forming the distal part of the zooidal orifice; ectooecium with transversely oval membranous window and granular endooecial surface underneath, with a small, central pore. Ovicellate zooids dimorphic, slightly wider distally, with orifices distinctly broader and campanulate in outline. Distal budding of autozooids and
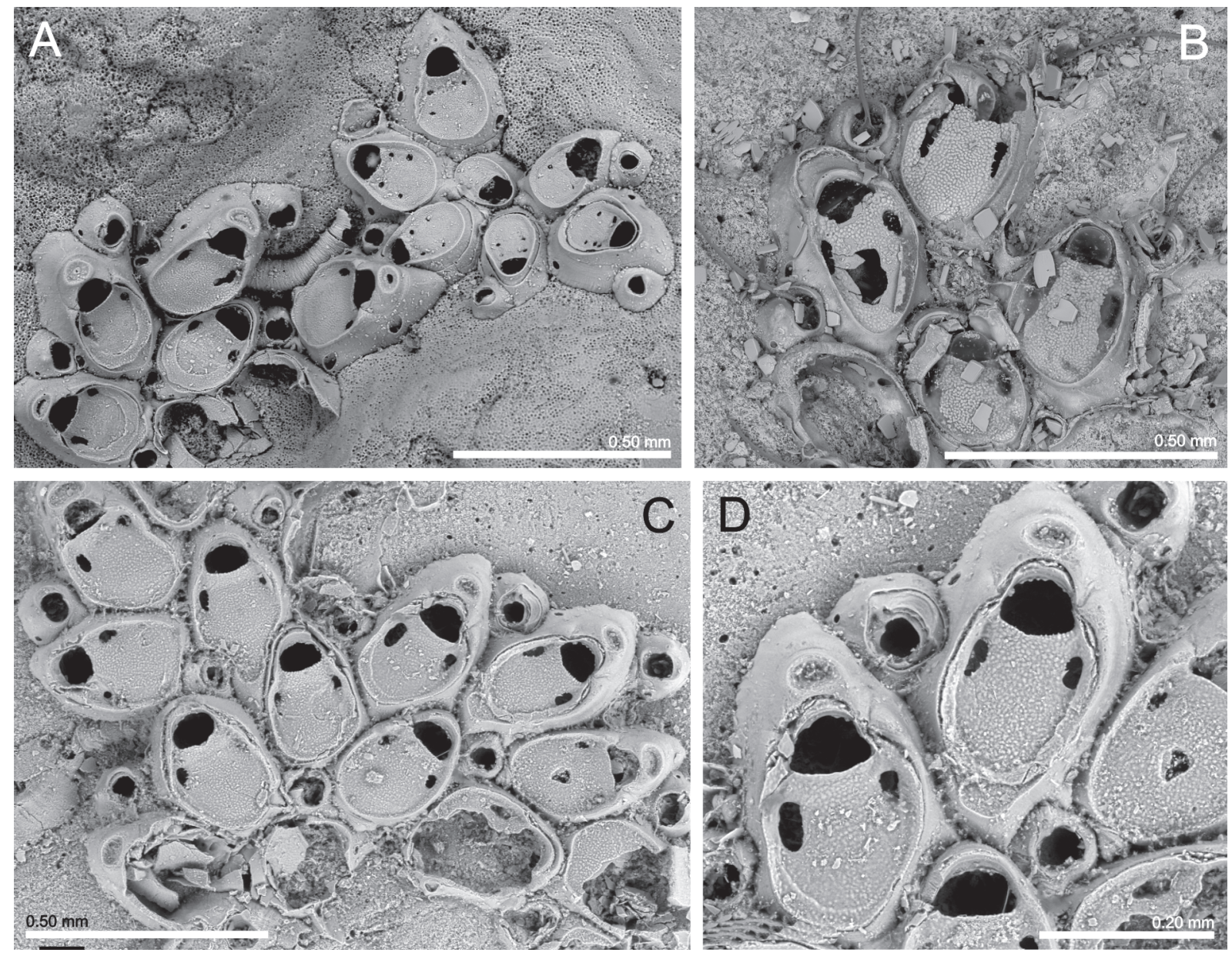

Fig. 5. Setosella margaritae sp. nov. A. A colony of S. margaritae sp. nov. (left) together with the colony of Setosella sp. (right) (see text and Reverter-Gil et al. 2012 as S. aff. cavernicola) (MHNUSC-Bry 93a). B. Damaged autozooids (one ovicelled, another with a developing ooecium) with three vibracula with setae (MHNUSC 10123: paratype). C. A colony with a damaged periancestrular area; note the intramural budding in several zooids (MHNUSC 10122: paratype). D. Same, detail showing two ovicelled zooids and a vibraculum with intramural budding. 
vibracula in ooecium-producing zooid retained. Ancestrula oval, with cryptocyst relatively smooth, occupying slightly less than half of the frontal area; opesia semi elliptical, with straight or slightly concave proximal border. Astogenesis beginning with one distal and two lateral autozooids; later zooids more irregularly arranged. The ancestrula also buds the two typical caudate vibracula of the genus: one short caudate, budded mid-laterally on the left side, and the other long caudate, budded distally, and sometimes curved to the right. On one occasion, however, this pattern was reversed, with the short vibraculum budded on the right side (Fig. 4C).

\section{Remarks}

The genus Setosella and all the species ascribed to it are at present well described under current standards. Setosella vulnerata, the type species of the genus, was redescribed by Souto et al. (2016). Rosso et al. (2020) redefined the genus itself as well as two known species (S. cavernicola Harmelin, 1977 and S. spiralis Silén, 1942) and three new species (S. alfioi Rosso, Di Martino \& Gerovasileiou, 2020, S. cyclopensis Rosso, Di Martino \& Gerovasileiou, 2020 and S. rossanae Rosso, Di Martino \& Gerovasileiou, 2020). Another species, S. folini Jullien, 1882, was redescribed by Souto et al. (2011). Finally, an undescribed species was reported from Galicia (NW Iberian Peninsula) as $S$. aff. cavernicola (see Reverter-Gil et al. 2012; Rosso et al. 2020).

Setosella margaritae sp. nov. differs from S. vulnerata (see redescription by Souto et al. 2016) as well as from $S$. cyclopensis, quite a similar species, by several characters: the vibracula of $S$. margaritae sp. nov. are much smaller, about half the size, and characteristically shifted laterally on the right side, often without exceeding the distal end of the autozooid (especially in ovicelled zooids), instead being distal or only slightly distolateral. The autozooids are oval and clearly smaller in S. margaritae sp. nov. The opesiules are shorter, oval to tear-shaped, instead slit-like or elongated; moreover, the opesiules are located closer to the opesia and directly beside the lateral walls of the zooid, instead of away from the opesia and the lateral walls. The window of the ectooecium in S. margaritae sp. nov. is transversally oval, whilst in S. vulnerata and S. cyclopensis it is roughly circular, much smaller in the former species, much larger in the latter. Finally, the colonies of $S$. margaritae sp. nov. are very small, encrusting mainly shell
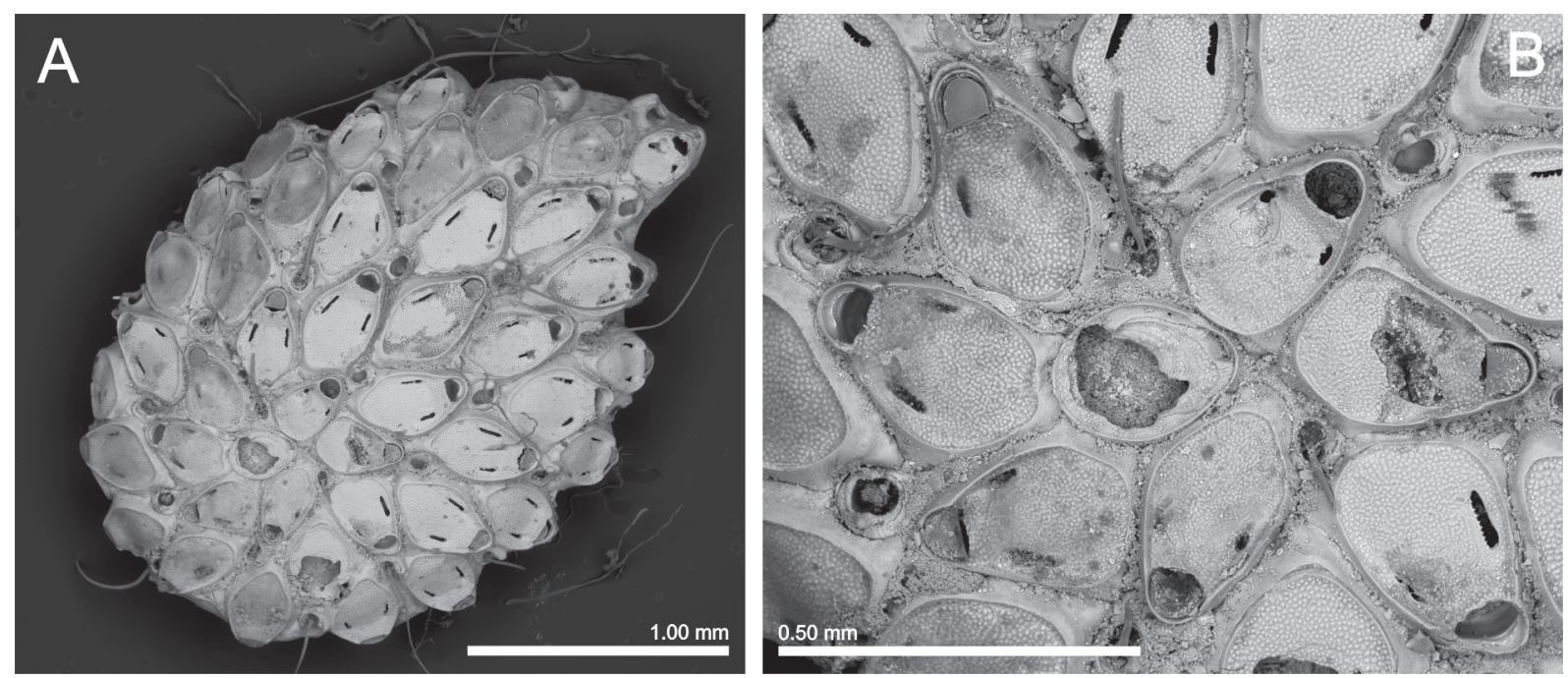

Fig. 6. A colony of Setosella vulnerata (Busk, 1860) collected at Alboran Island (Mediterranean Spain) (MNCN 25.03/3169). A. General view of the colony. B. The periancestrular area; note that the ancestrula was covered by a cryptocystal plate. 
fragments in shallow waters, as opposed to larger colonies encrusting mainly coarse sand, granules and fine pebbles in deeper waters in the other species.

At the same time, Setosella folini and S. alfioi differ from S. margaritae sp. nov. most obviously by their uniserial, free-living colonies. Setosella cavernicola, S. rossanae and Setosella sp. (as S. aff. cavernicola in Reverter-Gil et al. 2012) differ by their circular opesiules, four or even up to five in the latter two species. Finally, S. spiralis differs by the much larger autozooids and vibracula, with opesiules located further away from the opesia, and by colonies with spirally arranged zooids typically in a single rightcoiled row.

In the past, we have considered our own material to be similar to typical Setosella vulnerata. That is why we have cited deep material as Setosella sp. (see Reverter-Gil et al. 2012). But after the redescription of $S$. vulnerata by Souto et al. (2016) the situation has turned out to be just the opposite. Our previous records of $S$. vulnerata from shallow waters of Galicia (NW Iberian Peninsula) are here assigned to $S$. margaritae sp. nov.: from the Ría of Ferrol at 8-20 m depth, and from the Ría of Vigo at 9-23 m depth, both on shell fragments (Reverter-Gil \& Fernández-Pulpeiro 2001 and present data). These colonies are very small, formed by very few autozooids, but are fertile because ovicells are formed even in the first or second generations of periancestrular zooids (Figs 4A, C, 5A). Moreover, the material of $S$. vulnerata reported and figured by De Blauwe $(2006,2009)$, collected on shells at $10-25 \mathrm{~m}$ depth in Belgium (North Sea), also belongs to $S$. margaritae sp. nov. These colonies are larger than the Galician ones, but present the same characters, also including ovicells in the first or second generations of zooids (see De Blauwe 2009: figs 257-258; accessible also through WoRMS 2020: http://www.marinespecies.org/photogallery.php?album=709\&pic=25695\#photogallery and http://www.marinespecies.org/photogallery.php?album=709\&pic=25696\#photogallery). Moreover, the description and figures of S. vulnerata in Hayward \& Ryland (1998) fit the present description of $S$. margaritae sp. nov., at least the shallow-water material referred to there. Accordingly, the species is quite possibly distributed in shallow waters along the Atlantic coast of Europe, from the North Sea to at least the NW of the Iberian Peninsula. Its occurrence in other areas should be confirmed by reviewing previous citations of $S$. vulnerata. In a previous paper (Reverter-Gil et al. 2012), we already suggested that previous records of $S$. vulnerata might correspond to several different species.

Conversely, previous records of Setosella vulnerata in Atlantic Iberian deep waters (Cachucho [= Le Danois Bank], Galicia, Portugal and Gulf of Cadiz) actually belong to this species (see Jullien 1882; Calvet 1907; d'Hondt 1973, 1974; Hayward 1979; Harmelin \& d'Hondt 1992; Reverter-Gil \& Fernández-Pulpeiro 2001 only deep waters; Reverter-Gil et al. 2014; Souto et al. 2016), as is also the case for records published as Setosella sp. by Reverter-Gil et al. (2012) (see also Souto et al. 2016; Rosso et al. 2020).

There are a few more previous records of Setosella vulnerata in Iberian waters: the record from Alboran Island, at $118 \mathrm{~m}$ depth, made by Templado et al. (2006) actually corresponds to $S$. vulnerata (see material examined and Fig. 6) as well as the recent records published by Ramalho et al. (2020) in a nearby area between 95 and $440 \mathrm{~m}$ depth. However, the record from Columbretes Islands (Mediterranean Spain), at $80 \mathrm{~m}$ depth, made by Templado et al. (2002) actually belongs to $S$. cyclopensis (see material examined; unfortunately, this sample is currently unavailable for photography). Thus, this is the first Iberian record of this Mediterranean species. We have no further information about the records published by Zabala et al. (1993) from the Blanes Canyon at 180-350 m depth and by Madurell et al. (2013) from Cap de Creus at 104-225 m depth (Catalonia), but based on the given depths these records may belong to S. vulnerata or to $S$. cyclopensis. 
Following Souto et al. (2016) and Rosso et al. (2020), Setosella vulnerata is distributed in the Northeast Atlantic and the Mediterranean, although several Atlantic and Mediterranean occurrences still need to be checked. As already stated by Rosso et al. (2020) it is likely that $S$. vulnerata is actually restricted to deep habitats from the shelf break and the continental slope.

\section{Discussion}

As noted in the Introduction (see above), the bryozoological fauna of the Iberian Peninsula is one of the best known in European waters. Our own unpublished compilation, based on dozens of articles published over the last century and a half, and the revision of hundreds of samples - both our own and those of museum collections - has yielded approximately 540 recent species cited in this region. In comparison, only 556 species have been registered so far in a larger area as studied as the Mediterranean Sea as a whole, where there is an extensive bibliography on bryozoans dating back more than 200 years (Rosso \& Di Martino 2016). Moreover, all European waters combined have yielded 945 indigenous species according to Gordon et al. (2019). The description of two new species in a supposedly so wellknown area underlines the continued need for purely taxonomic and faunal works: they are key pillars to develop well-designed and useful biodiversity conservation policies (e.g., Wägele et al. 2011; Higgs 2017; Thomson et al. 2018).

\section{Acknowledgements}

We are grateful to several people and institutions: to J. Sánchez Almazán (MNCN) and to P. Lozouet and J. Mainguy (MNHN) for their valuable assistance during visits and the loan of material; to M.E. Spencer Jones (NHMUK) for the loan of material; to L. Ramalho for sending some unpublished SEM photographs of material from the Alboran Sea; to the staff of the MHNUSC, especially to M. González, J. Cutrín and X. Guerra for their kind support; and finally to the staff of the Servizo de Microscopía Electrónica (Universidade de Santiago de Compostela) for some of the SEM photographs. We are also very grateful to the anonymous reviewers, whose comments have allowed us to improve this work.

This work was partially supported by the projects 'Fauna Ibérica: Briozoos I (Ctenostomados y Queilostomados Anascos)' (CGL2006-04167) and 'Fauna Ibérica: Briozoos II (Familia Cribrilinidae - Familia Watersiporidae)' (CGL2010-22267-C07-02), co-financed by the Ministerio de Ciencia e Innovación, Spanish Government and FEDER. Javier Souto received support by the Austrian Science Fund (FWF, project number P 33733-B) and SYNTHESYS project ES-TAF-4852, which is financed by European Community Research Infrastructure Action under the FP7 Integrating Activities Program.

\section{References}

Barcia Leal M.C., Reverter-Gil O., Fernández Pulpeiro E. \& Ramil F. 1993. Bryozoaires sublittoraux de la Ría de Vigo (Galicia, Espagne nord-occidentale). Annales de l'Institut océanographique 69 (2): 249-259.

Busk G. 1852. An account of the Polyzoa, and sertularian zoophytes, collected in the Voyage of the Rattlesnake, on the coasts of Australia and the Louisiade Archipelago. In: MacGillivray J. (ed.) Narrative of the Voyage of the H.M.S. Rattlesnake 1: 343-402. T. and W. Boone, London.

Busk G. 1860. Zoophytology. Descriptions of new species of Polyzoa. Quarterly Journal of Microscopical Science 8: 123-125; 143-145; 213-214; pls 24-28.

Calvet L. 1907. Bryozoaires. In: Expéditions scientifiques du «Travailleur» et du «Talisman» pendant les années 1880-1883: 355-495. Masson et $\mathrm{C}^{\mathrm{ie}}$, Paris.

De Blauwe H. 2006. Bryozoa on shells from the Kwintebank, southern bight of the North Sea (Belgium). Bulletin de l'Institut royal des Sciences naturelles de Belgique 76: 125-138. 
De Blauwe H. 2009. Mosdiertjes van de zuidelijke bocht van de Noordzee. Determinatiewerk voor Belgie en Nederland. Vlaams Instituut voor de Zee, Oostende.

Gautier Y.-V. 1962. Recherches écologiques sur les Bryozoaires Chilostomes en Méditerranée occidentale. Recueil des Travaux de la Station marine d'Endoume 38: 1-435.

Gordon D.P., Bock P.E., Souto-Derungs J. \& Reverter-Gil O. 2019. A bryozoan tale of two continents: faunistic data for the Recent Bryozoa of Greater Australia (Sahul) and Zealandia, with European comparisons. In: Schmidt R., Reid C.M., Gordon D.P., Walker-Smith G. \& Percival I.P. (eds) Bryozoan Studies 2016. Proceedings of the Seventeenth International Bryozoology Conference: 1322. Australasian Palaeontologists, Sydney.

Gray J.E. 1848. List of the Specimens of British Animals in the Collection of the British Museum. Part 1. Centroniae or Radiated Animals. Trustees of the British Museum (Natural History), London.

Harmelin J.-G. 1977. Bryozoaires du banc de la Conception (Nord des Canaries). Campagne Cineca I de 'Jean Charcot'. Bulletin du Muséum national d'histoire naturelle, Série 3 492: 1057-1076.

Harmelin J.-G. \& d'Hondt J.-L. 1992. Bryozoaires des parages de Gibraltar (campagne océanographique BALGIM, 1984). 1—Chéilostomes. Bulletin du Muséum national d'histoire naturelle 14: 23-67.

Hayward P.J. 1979. Deep water Bryozoa from the coasts of Spain and Portugal. Cahiers de Biologie marine 20 (1): 59-75.

Hayward P.J. \& Ryland J.S. 1998. Cheilostomatous Bryozoa, Part 1. Aeteoidea-Cribrilinoidea. Synopses of the British Fauna 10. New Series. Linnean Society of London, London.

Higgs N. 2017. Taxonomy in trouble? Ocean Challenge 21 (2): 10-11.

Hincks T. 1862. Catalogue of the Zoophytes of South Devon and Cornwall. Annals and Magazine of Natural History (3) 9: 200-207. https://doi.org/10.1080/00222936208681210

Hincks T. 1877. On British Polyzoa Part II. Classification. Annals and Magazine of Natural History 20 (120): 520-532. https://doi.org/10.1080/00222937708682275

d'Hondt J.-L. 1973. Bryozoaires de la Campagne de la «Thalassa » (3-12 août 1967). Bulletin du Muséum national d'histoire naturelle 92: 365-386.

d'Hondt J.-L. 1974. Bryozoaires récoltés par la «Thalassa » dans le Golfe de Gascogne (Campagnes de 1968 à 1972). Cahiers de Biologie marine 15 (1): 27-50.

ICZN. 1999. International Code of Zoological Nomenclature. International Trust for Zoological Nomenclature, London.

Jullien J. 1882. Dragages du « Travailleur », Bryozoaires. Espèces draguées dans l'Océan Atlantique en 1881. Espèces nouvelles ou incomplètement décrites. Extrait du Bulletin de la Société zoologique de France 7: 1-33. https://doi.org/10.5962/bhl.title.4721

Levinsen G.M.R. 1909. Morphological and Systematic Studies on the Cheilostomatous Bryozoa. Nationale Forfatterers Forlag, Copenhagen. https://doi.org/10.5962/bhl.title.5690

Linnaeus C. 1758. Systemae naturae per regna tria naturae, secundum classes, ordines, genera, species, cum characteribus, differetiis, synonymis, locis, Ed. 10. Laurentii Salvii, Holmiae.

https://doi.org/10.5962/bhl.title.542

Madurell T., Zabala M., Domínguez-Carrió C. \& Gili J.M. 2013. Bryozoan faunal composition and community structure from the continental shelf off Cap de Creus (Northwestern Mediterranean). Journal of Sea Research 83: 123-136. https://doi.org/10.1016/j.seares.2013.04.013 
Norman A.M. 1864. On undescribed British Hydrozoa, Actinozoa and Polyzoa. Annals and Magazine of Natural History (3) 13: 82-90. https://doi.org/10.1080/00222936408681578

d'Orbigny A. 1851-54. Paléontologie française. Description des mollusques et rayonnés fossiles. Terrains crétacés, V. Bryozoaires. Victor Masson, Paris [pp. 1-188 (1851); pp. 185 bis-472 (1852); pp. 473-984 (1853); pp. 985-1192 (1854); pls 600-800. Dates as given by Sherborn (1899).]

Pallas P.S. 1766. Elenchus zoophytorum sistens generum adumbrationes generaliores et speciarum cognitarum succintas descriptiones cum selectis auctorus synonymis. Petrum van Cleef, HagaeComitum. https://doi.org/10.5962/bhl.title.6595

Ramalho L.V., Caballero-Herrera J.A., Urra J. \& Rueda J.L. 2020. Bryozoans from Chella Bank (Seco de los Olivos), with the description of a new species and some new records for the Mediterranean Sea. Marine Biodiversity 50 (6): 1-19. https://doi.org/10.1007/s12526-020-01119-y

Reverter-Gil O. 1995. Briozoos de la Ría de Ferrol. PhD Thesis, Universidade de Santiago de Compostela, Spain.

Reverter-Gil O. \& Fernández-Pulpeiro E. 2001. Inventario y cartografia de los Briozoos marinos de Galicia (N.O. de España). Nova Acta Científica Compostelana, Monografías 1, Santiago de Compostela.

Reverter-Gil O., Fernández-Pulpeiro E. \& Ramil F. 1992. Briozoos marinos de Galicia: Queilostomados. Boletín de la Real Sociedad española de Historia Natural (Sección Biológica) 88 (1/4): 99-115.

Reverter-Gil O., Souto J. \& Fernández-Pulpeiro E. 2012. New and little known species of Bryozoa from Iberian Atlantic waters. Zoosystema 34 (1): 157-170. https://doi.org/10.5252/z2012n1a7

Reverter-Gil O., Souto J. \& Fernández-Pulpeiro E. 2014. Annotated checklist of recent marine Bryozoa from continental Portugal. Nova Acta Cientifica Compostelana (Bioloxía) 21: 1-55. Available from $\mathrm{http} / / /$ www.usc.es/revistas/index.php/nacc/issue/view/208 [accessed 8 Jul. 2021].

Reverter-Gil O., Souto J. \& Fernández-Pulpeiro E. 2016. Bryozoa I. Ctenostomata. Fauna Ibérica 43. Museo Nacional de Ciencias Naturales, Madrid.

Rosso A. \& Di Martino E. 2016. Bryozoan diversity in the Mediterranean Sea: an update. Mediterranean Marine Science 17 (2): 567-607. https://doi.org/10.12681/mms.1706

Rosso A., Di Martino E. \& Gerovasileiou V. 2020. Revision of the genus Setosella (Bryozoa: Cheilostomata) with description of new species from deep-waters and submarine caves of the Mediterranean Sea. Zootaxa 4728 (4): 401-442. https://doi.org/10.11646/zootaxa.4728.4.1

Silén L. 1942. On spiral growth of the Zoaria of certain Bryozoa. Arkiv för Zoologi, Stockholm 34A (2): $1-22$.

Smitt F.A. 1868. Kritisk förteckning öfver Skandinaviens Hafs-Bryozoer (IV). Öfversigt af Kongliga Vetenskaps-Akademiens Förhandlingar 25 (Suppl.): 3-230.

Souto J., Reverter-Gil O. \& Fernández-Pulpeiro E. 2011. Redescription of some bryozoan species originally described by J. Jullien from Iberian waters. Zootaxa 2827: 31-53.

https://doi.org/10.11646/zootaxa.2827.1.2

Souto J., Berning B. \& Ostrovsky A.N. 2016. Systematics and diversity of deep-water Cheilostomata (Bryozoa) from Galicia Bank (NE Atlantic). Zootaxa 4067 (4): 401-459.

https://doi.org/10.11646/zootaxa.4067.4.1

Templado J., Calvo M., García Carrascosa A.M., Boisset F. \& Jiménez J. 2002. Flora y Fauna de la Reserva Marina de las Islas Columbretes. Ministerio de Agricultura, Pesca y Alimentación, Madrid. 
Templado J., Calvo M., Moreno D., Flores A., Conde F., Abad R., Rubio J., López-Fé C.M. \& Ortiz M. 2006. Flora y Fauna de la Reserva Marina y Reserva de Pesca de la Isla de Alborán. Ministerio de Agricultura, Pesca y Alimentación, Madrid.

Thomson S.A. et al. 2018. Taxonomy based on science is necessary for global conservation. PLoS Biology 16 (3): e2005075.

Vieira L.M. \& Spencer Jones M.E. 2012. The identity of Sertularia reptans Linnaeus, 1758 (Bryozoa, Candidae). Zootaxa 3563: 26-42. https://doi.org/10.11646/zootaxa3563.1.2

Vieira L.M., Spencer Jones M.E. \& Winston J.E. 2013. Cradoscrupocellaria, a new bryozoan genus for Scrupocellaria bertholletii (Audouin) and related species (Cheilostomata, Candidae): taxonomy, biodiversity and distribution. Zootaxa 3707 (1): 1-63. https://doi.org/10.11646/zootaxa.3707.1.1

Wägele H., Klussmann-Kolb A., Kuhlmann M., Haszprunar G., Lindberg D., Koch A. \& Wägele J.W. 2011. The taxonomist - an endangered race. A practical proposal for its survival. Frontiers in Zoology 8 : 1-7. https://doi.org/10.1186/1742-9994-8-25

WoRMS. 2020. World Register of Marine Species. Available from http://www.marinespecies.org. [accessed 19 Nov. 2020].

Zabala M. 1986. Fauna dels briozous dels Països Catalans. Arxius de la Secció de Ciències 84: 1-836.

Zabala M. \& Maluquer P. 1988. Illustrated keys for the classification of Mediterranean Bryozoa. Treballs del Museu de Zoologia, Barcelona 4: 1-294.

Zabala M., Maluquer P. \& Harmelin J.-G. 1993. Epibiotic bryozoans on deep-water scleractinian corals from the Catalonia Slope (western Mediterranean, Spain, France). Scientia Marina 57: 65-78.

Manuscript received: 9 March 2021

Manuscript accepted: 1 June 2021

Published on: 15 July 2021

Topic editors: Rudy Joqué

Desk editor: Charlotte Gérard

Printed versions of all papers are also deposited in the libraries of the institutes that are members of the EJT consortium: Muséum national d'histoire naturelle, Paris, France; Meise Botanic Garden, Belgium; Royal Museum for Central Africa, Tervuren, Belgium; Royal Belgian Institute of Natural Sciences, Brussels, Belgium; Natural History Museum of Denmark, Copenhagen, Denmark; Naturalis Biodiversity Center, Leiden, the Netherlands; Museo Nacional de Ciencias Naturales-CSIC, Madrid, Spain; Real Jardín Botánico de Madrid CSIC, Spain; Zoological Research Museum Alexander Koenig, Bonn, Germany; National Museum, Prague, Czech Republic. 